\title{
Impact of Antibiotics Residues on Food Microbiological Quality in Togo: Cases of Chicken Meat and Eggs
}

Banfitebiyi GAMBOGOU ( $\sim$ dinhog39@gmail.com )

Institut Togolais de Recherche Agronomique https://orcid.org/0000-0003-2474-9465

Abla Judith Estelle GNAMEY

université de Lomé; Harbin medical University

Raouf T. MENSAH

Université of Lomé

Délia Carmen DIABANGOUAYA

Université de Lomé

Messanh KANGNI-DOSSOU

Universite de Lome

Yaovi A. AMEYAPOH

Université de Lomé

\section{Data Article}

Keywords: bacteriological quality, antibiotic residues, chicken meats and eggs, Lomé, Togo

Posted Date: September 8th, 2020

DOl: https://doi.org/10.21203/rs.3.rs-71572/v1

License: (c) (i) This work is licensed under a Creative Commons Attribution 4.0 International License. Read Full License 


\section{Abstract}

Purpose: The use of antibiotics in veterinary medicine has greatly promoted the intensification of animal production in recent decades. However, the improper use of these veterinary antibiotics causes their residues to be present in foodstuffs of animal origin and thus creates public health issues. Thus, the aim of this study is to assess the impact of the presence of antibiotic residues on bacteriological quality of meat and chicken eggs in Togo.

Methodology: a survey was carried out among hundred chicken farmers in six markets in the city of Lomé. Then, AFNOR's routine method and the rapid Test method (Premi test) were used to assess the bacteriological quality and the presence of antibiotics in Chicken meats (54 samples) and eggs (36 samples). The statistical analysis is done with software SPSS v25.

Results: The results of surveys of our operators have shown that broilers and laying hens are the most represented in the six markets. None of the interviewees ever received any training in biosecurity, food security and good hygiene practice. Out of 90 samples analyzed, $18.89 \%$ are positive for antibiotic residues with $99.51 \%$ of correlation between antibiotic residues and origin of the sample $(p<0.05)$. Regarding microbiological quality, $16,7 \%(13 / 78)$ of compliance sample are positive to antibiotic residues and $33.3 \%(4 / 12)$ of no compliance sample are positive for antibiotic residues with $92.91 \%$ of correlation between microbiology quality and antibiotics residues $(p<0.05)$.

Conclusion: The presence of antibiotic residues in the chicken meat and eggs influence the detection of microorganisms. This leads to a food security problem in Togo.

\section{Introduction}

Antibiotics are natural antibacterial agents of biological, synthetic or semi-synthetic origin which prevent the multiplication of bacteria or lead to their destruction by an action at the level of one or more metabolic stages essential to the life of the bacteria (Abdeladim, 2019). However, in breeding, to guarantee a yield and ensure the health of poultry, breeders use antibiotics for curative and prophylactic purposes in various ways, among others, a growth promoter for an increase in the speed of growth or as a curative drug or prophylactic to prevent and treat infectious diseases that can cause significant morbidity and be associated with mortality.

The use of these antibiotics in breeding can leave traces of antibiotics called antibiotic residues, which can be found in the products of consumed animals (muscles, eggs, etc.) (Corvaglia, 2006; Mensah et al., 2014a; Okombe et al., 2017). The presence of these residues is due to the non-respect of the waiting times after the administration of antibiotics, to the non-consultation of veterinarians before the use of antibiotics, in the absence of prior training in animal production in the type of farming, intensive or extensive, practiced on the farm (Okombe, et al., 2016; Traoré and Tamini, 2019). Thus, there is a Maximum Residue Limit (MRL) (Traoré and Tamini, 2019) for most antibiotics used in veterinarian medicine, for each commodity of animal origin and for each species (Mensah et al., 2014a). In case of 
non-compliance of waiting times and MRLs, antibiotic residues can represent a significant risk for consumers, among other things, allergies, cancers, changes in the intestinal flora, fetotoxicity (Mensah et al., 2014c). In addition, they can favor the selection of resistances in natural environments attacked.

In Africa, and especially in West Africa, only microbial pathogens, pesticide residues and aflatoxins have been the subject of a process to protect the safety of food intended for human consumption. These dangers have been most reported as threatening public health. In April 2007, the eight WAEMU countries (Benin, Burkina-Faso, Côte d'Ivoire, Mali, Niger, Guinea-Bissau, Senegal and Togo) adopted regulation 07/2007 / CM / WAEMU on security health of plants, animals and food in the WAEMU zone (Bedda and Barkat, 2019; Dognon et al., 2018). Recently, in 2010 and 2011, two training sessions were held in Benin to familiarize the different countries with the theoretical framework of health risk analysis (Mensah et al., $2014 a, b, c)$. Concerning residues of veterinary drugs in food, WAEMU does not have a functional system for detecting drug residues in food of animal origin yet. However, the experts responsible for validating the files are rather attentive to the waiting times in order to minimize drug residues in food. Only very few studies have looked at antimicrobial residues affecting food safety (Laurentie et al., 2002). However, failure to meet wait times in developing countries results in exposure to high levels of antimicrobial residues in these countries (Abdeladim, 2019; Bedda and Barkat, 2019; McEwen et al, 1991).

The free sale of these antibiotics facilitates their accessibility to farmers who are neither trained nor informed about the use of these antibiotics, nor respect of the waiting period (Bedda and Barkat, 2019; Châtaigner and Stevens, 2003). Today, according to the FAO, priority is given to the health and food safety of consumers by a physico-chemical and microbiological analysis of foodstuffs (Abiola et al., 2005). However, very few studies have been done in Togo in this area. Therefore, it is essential to ensure the health safety of consumers by an analysis of the quality of poultry products, in particular marketed chicken meat and eggs, which is a growing sector in Togo (FAO, 2015). It should be noted that since 2005, the Maritime Region alone has owned more than half of the commercial poultry farms, ie $82 \%$ in Togo (Dao, 2010). The objective of our study is therefore to determine the bacteriological quality and the presence of antibiotic residues in the meat and eggs of hens marketed in poultry markets in Lomé.

\section{Material And Methods}

\section{Study zone}

Lomé is the capital of Togo, a country located in West Africa. The city is located in the southwest of the country and extends on the shore of the Gulf of Guinea. It occupies a total area of $333 \mathrm{~km}^{2}$ with several agglomerations among others: Aflao, Agbalépédo, Akodésséwa, Baguida, Kanyikopé, Kélékougan, Agoè, Zanguéra... It is located 150 kilometers away from Cotonou and 200 kilometers away from Accra (Dao, 2010).

Lomé, the capital is renowned for being an industrial, commercial and administrative city. The study was carried out in December 2019 with traders of poultry products (chicken eggs, broilers, laying hens, 
traditional hens and frozen hens imported or not) in six (6) markets including Adawlato, Adidogomé, Agoè, Akodesséwa, Gbossimé, and Hedrzanawè.

\section{Collection of data}

A preliminary survey was previously carried out on the knowledge, attitudes and practices of the use of antibiotics in the chicken trade. Then samples were taken from its stores for analysis. Business managers were previously informed of the study and their agreements were obtained before the activities were carried out.

The information was collected through a smartphone questionnaire for chicken traders. This questionnaire was designed on Google Form and contains 16 questions to the multiple-choice system, the merchant only having to tick the box corresponding to his choice. This system has the advantage of allowing better rapid exploitation of the data obtained.

All of the data was recorded on Google Form Excel and transferred to the Microsoft Excel 2013 for analysis by SPSS version 25 .

\section{Sampling}

According to study data previously carried out in Togo in 2015 (Dao, 2010), 264 operators of poultry products were registered in 2010 in the maritime region with 135 operators in Lomé. From this study with a frequency of $50 \%$ and a confidence interval of $95 \%$ and $5 \%$ error, the sample size calculated was 100 operators. As for bacteriological analyzes and the detection of antibiotic residues, 54 meat samples were collected, including 36 from imported and 18 from local, as well as 36 samples of chicken eggs (18 sample from local and 18 sample from imported).

\section{Sample preparation}

Chickens are slaughtered in order to remove parts containing muscle, especially the wings and thighs. These pieces are then individually put in freezer bags and then in the freezer at $-18{ }^{\circ} \mathrm{C}$. For frozen chickens, the thighs and wings are taken directly from the carcass.

The eggs were acquired in the six markets of Lomé and stored at the temperature of the Laboratory.

\section{Detection of antibiotic residues}

The analyzes took place in the Laboratory of Microbiology and Quality Control of Foodstuffs (LAMICODA) of the Higher School of Biological and Food Techniques (ESTBA) of the University of Lomé.

The alternative analysis method Premi®Test reference RBP 31 / 02-04 / 11 validated by AFNOR was used. It is a rapid test for the preventive detection of antibiotic residues in chicken meat and eggs according to the Method used by Diabangouaya (2017) in her study. 
About two (02) $\mathrm{cm}^{3}$ pieces of meat were removed and pressed using a meat press to extract the meat juice. Then $100 \mu \mathrm{l}$ of the meat juice is transferred to the agar in a Premi ${ }^{\circledR} T e s t$ vial. After standing for 20 minutes at room temperature, the vials were rinsed twice with distilled water to remove the meat juice. The vials are then incubated at $64^{\circ} \mathrm{C}$ for 3 hours. The result is negative if the agar changes from yellow to purple after three (03) hours.

\section{Analysis of bacteriological quality}

The bacteriological analyzes took place at the Laboratory of Microbiology and Quality Control of Foodstuffs (LAMICODA) of the Higher School of Biological and Food Techniques of the University of Lomé.

The samples of $10 \mathrm{~g}$ are weighed in $100 \mathrm{ml}$ bottles containing $90 \mathrm{ml}$ of Tryptone Salt (TS) for the detection of bacteria. $25 \mathrm{~g}$ of samples are weighedin the $250 \mathrm{ml}$ bottles containing $225 \mathrm{ml}$ of Buffered Peptone water (EPT) for the detection of Salmonellasp. The mix (sample and media solution) are mixed according to the standardized methods of the French Association for Standardization (AFNOR). After 45 minutes of resting of the ground material, decimal dilutions of $100,10^{-1}, 10^{-2}$ and $10^{-3}$ were made. Different methods were used depending on the germ sought (Table 1).

Table 1:

Different techniques for counting germs

\begin{tabular}{|llll|}
\hline Germs searched & Media & $\begin{array}{l}\text { Standard } \\
\text { methods }\end{array}$ & $\begin{array}{l}\text { Temperature / } \\
\text { incubation time }\end{array}$ \\
\hline $\begin{array}{l}\text { Total mesophilic flora } \\
\text { (FMT) }\end{array}$ & PCA & $\begin{array}{l}\text { NF V08-051, Fév. } \\
1999\end{array}$ & $30^{\circ} \mathrm{C} / 24-72 \mathrm{~h}$ \\
\hline Enterobacterium & VRBL & $\begin{array}{l}\text { NF V08-050, Déc. } \\
1992\end{array}$ & $30^{\circ} \mathrm{C} / 24-48 \mathrm{~h}$ \\
\hline E. coli & CM1046 Brillance ${ }^{\mathrm{TM}}$ Ecoli & & $37^{\circ} \mathrm{C} / 24 \mathrm{~h}$ \\
\hline $\begin{array}{l}\text { Sulphite-reducing } \\
\text { anaerobes (ASR) }\end{array}$ & TSN & $\begin{array}{l}\text { XP V08-061, Oct. } \\
1996\end{array}$ & $44^{\circ} \mathrm{C} / 48 \mathrm{~h}$ \\
\hline Staphylococcus aureus & BP & $\begin{array}{l}\text { NF V08-057-1, } \\
\text { Nov. 1994 }\end{array}$ & $37^{\circ} \mathrm{C} / 24-48 \mathrm{~h}$ \\
\hline Salmonella $s p$ & EPT, Rappaport, Hektoen, & $\begin{array}{l}\text { NF V08-052, Mai } \\
1997\end{array}$ & $37^{\circ} \mathrm{C} / 24 \mathrm{~h} /$ étape \\
\hline
\end{tabular}

PCA: Plate Count Agar; VRBL: Violet Red Bile Lactose Agar; BP: Baird Parker, TSN: Tryptone Sulfite Neomycin; EPT: Buffered Peptone Water.

\section{Statistical analysis}

The statistical analysis of sample are done using software SPSS v25. The correlation analysis is done using Pearson test of $\mathrm{Khi}^{2}$ with $\mathrm{p}$ value 0.05 . 


\section{Results}

\section{Socio-demographic characteristics of sales for chickens at the market}

Both men and women carry out the poultry trade in the study area. Men are mainly encountered in the Gbossimé market, mainly sell local guinea fowl, and secondarily sell local pigeons. The age of the retailers varies between 25 and 30 years and in most cases are single. The age of the wholesalers varies between 35 and 45 and they are all married. These local guinea fowl merchants are from the country's northern region and have received no training in poultry farming. Their level of education is generally very low (primary level). Women are mainly involved in the sale of poultry and therefore chickens, ducks, pigeons and turkeys in all markets in the study area. Their age varies between 30 and 50 years. For them it is an activity acquired by inheritance. Among them are wholesalers and retailers.

\section{Socio-demographic characteristics of sales staff for frozen chickens}

During the investigation, it was found that the owners of establishments selling frozen meat represent $88.6 \%$, of which $1.6 \%$ are women and $98.4 \%$ are men. They run their establishment themselves. The rest corresponding to $11.4 \%$ are civil servants and come to their establishment only during weekends. These owners are all educated at various levels: $6 \%$ in primary, $86 \%$ in secondary and $8 \%$ at university level. However, none has been legally trained in the field of food quality.

\section{Marketing practices for poultry products}

Out of the merchants surveyed, there were $92 \%$ engaged in the poultry trade as a permanent activity, while $8 \%$ used the holiday season to do so. Wholesalers mainly coming from the Savannah region supply the market of Gbossimé, large supplier of the population of Lomé in poultry. They are transported in the cages by car, twice a week. Traders from other markets claim to stock up in the villages and outskirts of the city of Lomé.

\section{Distribution of speculations in the study area}

The rate of each speculation is shown in Figure 1. Out of 100 surveyed into the six markets of the city of Lomé, the association of broilers and laying hens represents $46.1 \%$ of speculations followed by broilers $28.40 \%$ of speculations.

\section{Knowledge of antibiotic use}

Among the respondents, $100 \%$ say that broilers and laying hens are treated at start-up and prophylaxis compared to $0 \%$ for traditional hens. For the treatment before the sale, $82.20 \%$ asserted that the hens are treated before the sale including $66.20 \%$ for the treatment of traditional hens against $16 \%$ for the treatment of broilers and laying hens. Thus, $70 \%$ and $30 \%$ of respondents say that they use antibiotics respectively for curative and prophylaxis. Tetracolivit, Alyseryl, Keproceryl and Limoxin are the most cited antibiotics at $21 \%, 19 \%, 14.6 \%$ and $13 \%$ respectively. Traders recorded ignorance of the waiting times 
after the administration of antibiotics and no previous training in animal production in the type of breeding.

\section{Knowledge of Good Hygiene and Biosecurity Practices}

In terms of biosecurity, it should be noted that no measure is applied since the structures and organization of the markets themselves do not lend themselves to it. The same goes for well-being since in these markets, poultry are for the most part tied up and placed on the ground without water and fed only with corn bran or cubed bran.

The traditional hens spent less than two days on the shelves according to $59 \%$ of the traders against $66.66 \%$ of the traders who claim that the broilers and laying hens spent more than 2 days on the displays. Regarding eggs, $58.33 \%$ of traders say that the eggs spent more than 07 days on the shelves.

The operators clean the buildings and the work equipment at different frequencies. The cleaning of the feeders and drinkers is daily for any trader of chicken, while the other cleaning elements are monthly with $84.62 \%$ of the traders of chickens who remove the litter monthly.

As for frozen chicken traders, $90 \%$ say they clean the equipment for each use. All of them (100\%) have no relay energy source during load shedding. They also claim that water for equipment maintenance is replaced for each use. Among them, only $56 \%$ of the sellers known the frozen date production and expiration.

\section{Analysis of antibiotic residues in muscles and chicken eggs}

The detection of antibiotic residues in chicken egg and meat samples is shown in Table 2. Antibiotic residues were found in $18.7 \%$ of the samples. It turns out that imported meat (33.3\%) and eggs samples (33.33\%) have the highest antibiotic residue levels. The lowest antibiotics residues detection are shown among the local broilers (5.6\%). 
Table 2:

Antibiotic residues detection according their origin.

\begin{tabular}{|c|c|c|c|}
\hline \multirow[b]{2}{*}{ Origin } & \multirow[b]{2}{*}{ Sample } & \multicolumn{2}{|c|}{ Antibiotics residues } \\
\hline & & Negative, n (\%) & Positive, n (\%) \\
\hline \multirow[t]{2}{*}{ Imported } & Frozen chicken meat $(\mathrm{N}=18)$ & $12(66,7 \%)$ & $6(33,3 \%)$ \\
\hline & Chicken eggs $(\mathrm{N}=18)$ & $12(66,7 \%)$ & $6(33,3 \%)$ \\
\hline \multirow[t]{3}{*}{ Local } & Chicken eggs ( $\mathrm{N}=18)$ & $16(88,9 \%)$ & $2(11,1 \%)$ \\
\hline & Chicken meat $(\mathrm{N}=18)$ & $16(88,9 \%)$ & $2(11,1 \%)$ \\
\hline & Broilers $(\mathrm{N}=18)$ & $17(94,4 \%)$ & $1(5,6 \%)$ \\
\hline \multicolumn{2}{|c|}{ Total $(\mathrm{N}=90)$} & $73(80,2 \%)$ & $17(18,7 \%)$ \\
\hline
\end{tabular}

\begin{tabular}{|lccc|}
\hline \multicolumn{4}{|c|}{ Khi $^{2}$ Tests between antibiotic residues and samples origin distribution } \\
\hline & Value & ddl & Asymptotic signification \\
\hline Pearson Khi ${ }^{2}$ test & 99,506 & 4 & 0,000 \\
\hline Likelihood ratio & 19,571 & 4 & 0,034 \\
\hline N valid of observations & 90 & & \\
\hline N: Number of samples examined & \\
\hline
\end{tabular}

\section{Analysis of the bacteriological quality of muscle samples and chicken eggs}

The correlation between bacteriological quality and antibiotics residues detection into the samples is shown in Table 3. According to the food bacteriology criteria of the European Union 2007 Directive, among the $18.7 \%$ (17/90) of sample positive to antibiotics residues detection test, $33.3 \%(4 / 12)$ are no compliant and $16.7 \%(13 / 78)$ of sample are compliant. 
Table 3:

Correlation the bacteriological quality and antibiotic residues of the sample examined.

Antibiotics residues

Negative, $\mathrm{n}$

$(\%)$

$65(83,3 \%)$

$8(66,7 \%)$

$73(80,2 \%)$
Positive, $\mathrm{n}$

$(\%)$

$13(16,7 \%)$

2007

Number of samples no compliant to EU bacteriological criteria 2007

Total

$\mathrm{n}$ : Number of positive or negative sample.

\begin{tabular}{|lccc|}
\hline \multicolumn{4}{|c|}{ Khi $^{2}$ Tests between antibiotic residues and bacteriological food quality } \\
\hline & Valeur & ddl & Signification asymptotique (bilatérale) \\
\hline Pearson Khi ${ }^{2}$ test & 92,907 & 1 & 0,000 \\
\hline Likelihood ratio & 12,676 & 1 & 0,013 \\
\hline N valid of observations & 90 & & \\
\hline N: Number of samples examined
\end{tabular}

\section{Discussion}

The sanitary quality of food is a major public health problem. To overcome these problems, it is important to have an inventory of hygiene practices and the use of antibiotics.

Marketing practices for poultry products have shown that men are the most represented and exercise this profession permanently or occasionally at the end of the holiday season. As for speculation, broilers and laying hens are the most represented with $46.1 \%$. This could be explained by the increased interest in the consumption of chicken meat in the study area. According to Dao (Dao, 2010), the production of broilers was 27,809 in Togo and according to the FAO (FAO, 2015), imports of poultry meat, intended for marketing, increased by almost 8,600 tons from 2006 to 2008 in Togo.

Regarding good hygiene practices and the use of antibiotics, no respondent received training in this area. Each breeder or trader has their equipment maintenance frequency and does not consult a veterinarian to administer antibiotics. This is explained by an absence of quality standards and good hygiene practice in the sector. Boulechbak and Hanou (2019) made the same observations during their study in Algeria on antibiotic therapy practices in poultry farming. Thus, training in poultry farming and the development of 
standards for rearing and their application is a necessary condition that could contribute to the improvement of productivity and national production.

In this study, the proportion of samples positive for antibiotic residues is relatively high (18.7\%). Among the samples analyzed in the six Lomé poultry markets, imported frozen and eggs chickens are the types of products that contain the antibiotic residues. The presence of residues in these products could be due to non-compliance with waiting times before slaughter, or to the limit threshold for the use of antibiotics. This result corroborates that of the FAO report in 2015 where it is shown that the production system of eggs and broiler chickens is dominated by self-medication and that the breeders are neither supervised nor controlled and are mostly trained in the field. These results in poor quality egg production throughout the chain (FAO, 2015). The production of quality eggs would therefore require the use of veterinary pharmaceuticals, egg quality control and above all the implementation of risk reduction strategies according to regulations (Abdeladim, 2019; Ahmed and Ben Hamida, 2019).

The bacteriological quality of chicken eggs and meats analyzed was non-compliant compared to the recommendation of the European Union criteria for 2007 and these non-compliant meats contained antibiotic residues. We detected $13(16.7 \%)$ of conform samples positive to the antibiotic residues. This compliance with the standard may be due to the presence of antibiotics in its meats, which, by their bacteriostatic action, a momentary inhibitor on the growth of pathogenic germs, can prevent detection or enumeration during microbiological quality control (Abdeladim, 2019). The presence of substances with antibiotic activity does not hamper the detection of pathogenic germs. This could be either due to the insensitivity of the germ to the antibiotic used or to the fact that the dose present is too low to have bacteriostatic activity. However, when a sample shows antimicrobial activity and does not contain a pathogenic germ, it is impossible to confirm the absence of microbial contamination before slaughter. The studies of Frères et al. (1971) and Franco et al. (1990) reveal these aspects when the poor condition of a horse's carcass was observed on a sample sent to the veterinary services of slaughterhouses. However, no pathogenic germ could be detected there. It also appears that the muscle of the carcass contained an antibacterial substance (tetracycline) at a concentration around $1 \mathrm{mg} / \mathrm{kg}$ (Freres et al., 1971). It is likely that, in this particular case, the antibiotic would have prevented the revelation of pathogenic germs.

\section{Conclusion}

The city of Lomé and its agglomerations constitute the largest market for the sale of poultry products because of the concentration of the population and the standard of living of the latter. Poultry markets need to be redeveloped to facilitate the implementation of biosecurity and welfare measures. Merchants should be regularly educated on hygiene and poultry welfare issues in order to protect the health of consumers. Public awareness of the quality of the poultry products it consumes is important. Hygiene services, veterinary services must be able to inspect the places where these products are prepared and their staff. In addition, a larger-scale qualitative and / or quantitative study must be carried out to better 
take into account the general situation of antibiotic residues and the antibiotic resistance profile of germs isolated in poultry products.

\section{Declarations}

\section{Conflict of interest:}

authors declare that they are no conflict of interest

\section{Funding:}

it is not applicable

\section{Research involving human participants and/or animals:}

it is not applicable

\section{Consent:}

it is not applicable

\section{Ethical approval:}

it is not applicable

\section{Acknowledgements:}

we acknowledge all people who collaborated in this study such as Dr Anani Kokou, Dr Soncy Kouassi, Dr Djeri Bouraïma and Professeur Karou Simplice Damintoti.

\section{Author contribution:}

Yaovi A. AMEYAPOH and Banfitebiyi GAMBOGOU. conceived and designed the experiments; Messanh KANGNI-DOSSOU, Abla Judith Estelle GNAMEY and Banfitebiyi GAMBOGOU, performed the experiments; Yaovi A. AMEYAPOH and Délia Carmen DIABANGOUAYA contributed to the reagents/analysis tools; Raouf T. MENSAH, Abla Judith Estelle GNAMEY and Banfitebiyi GAMBOGOU analyzed the data and drafted the manuscript; Banfitebiyi GAMBOGOU wrote the paper. Yaovi A. AMEYAPOH supervised the research.

\section{References}

1. Abdeladim, A. (2019). Usage des antibiotiques dans l'élévage de volailles et la résistance bactérienne et son impacte sur la santé humaine. thèse de doctorat.

2. Abiola, F., Diop, M., Teko-Agbo, A., Delepine, B., Biaou, F., Roudaut, B., . . . Sanders, P. (2005). Residus d'antibacteriens dans le foie et le gesier de poulets de chair dans les regions de Dakar et de Thies (Senegal). Revue de Médecine Vétérinaire, 156(5), 264-268. 
3. Ahmed, F. Z., \& Ben Hamida, H. (2019). Détection des résidus d'antibiotiques dans la viande du poulet de chair dans la région de M'sila. Université Mohamed BOUDIAF de M'Sila.

4. Bedda, I., \& Barkat, B. (2019). Marché des produits pharmaceutiques vétérinaires dans la région de M'Sila: impact de la qualité sur l'acceptabilité des éleveurs. Université Mohamed BOUDIAF de M'Sila.

5. Boulechbak, M., \& Hanou, M. (2019). Enquête sur les pratqiues de l'antibiothérapie en élevage avicole. INSTITUT DES SCIENCE VETERINAIRE-BLIDA-

6. Châtaigner, B., \& Stevens, A. (2003). Investigation sur la présence de résidus d'antibiotiques dans les viandes commercialisées à Dakar. Rapport projet PACEPA. Ministère de l'Élevage-Service de coopération et d'action culturelle-Institut Pasteur.

7. Corvaglia, A. R. (2006). Rôle des résidus d'antibiotiques dans l'environnement hydrique sur la sélection et la diffusion de bactéries résistantes des genres" Aeromonas"," Acinetobacter" et" Legionella". University of Geneva.

8. Dao, B. (2010). Recensement (qualitatif/quantitatif) de toutes les exploitations avicoles et des structures de la filière dans toutes les régions du pays. Rapport FAO/OSRO/TOG/801/EC, 36p.

9. DIABANGOUAYA, D. C. (2017). Recherche de résidus médicamenteux vétérinaires dans les viandes au Togo : "Cas de volailles à Lomé". Mémoire de Master non publié.

10. Dognon, S. R., Douny, C., Salifou, C. F. A., Ahounou, G. S., Dougnon, J., Sessou, P., . . Scippo, M.-L. (2018). Qualité des antibiotiques vétérinaires utilisés en Afrique de l'Ouest et méthodes de détection de leurs résidus dans les denrées alimentaires. Journal of Animal \& Plant Sciences, 36(2), 58585877.

11. FAO. (2015). Secteur Avicole Togo. Revues nationales de l'élevage de la division de la production et de Abdeladim, A. (2019). Usage des antibiotiques dans l'élévage de volailles et la résistance bactérienne et son impacte sur la santé humaine.

12. Franco, D. A., Webb, J., \& Taylor, C. E. (1990). Antibiotic and sulfonamide residues in meat: Implications for human health. Journal of food protection, 53(2), 178-185.

13. Freres, D., Valdebouze, P., \& Delort-Laval, J. (1971). Recherche de résidus à activité antibiotique dans les tissus animaux II.-Enquête sur les viandes du commerce. Bulletin de l'Académie vétérinaire de France.

14. Laurentie, M., Creff-Froger, C., \& Gaudin, V. (2002). Surveillance des résidus d'antibiotiques. Apport des méthodes de spectrométrie de masse à l'identification des contaminants. Bulletin de l'Académie vétérinaire de France.

15. McEwen, S. A., Black, W. D., \& Meek, A. H. (1991). Antibiotic residue prevention methods, farm management, and occurrence of antibiotic residues in milk. Journal of dairy science, 74(7), 21282137.

16. Mensah, S., Koudandé, O., Sanders, P., Laurentie, M., Mensah, G., \& Abiola, F. (2014). Résidus d'antibiotiques et denrées d'origine animale en Afrique: risques de santé publique. Revue scientifique et technique (International Office of Epizootics), 33, 975-986. 
17. Mensah, S., Laurentie, M., Salifou, S., Sanders, P., Mensah, G., Abiola, .Koudandé, O. (2014). Usage des antibiotiques par les éleveurs bovins au centre du Bénin, quels risques pour la santé publique? Bulletin de la Recherche Agronomique du Bénin (BRAB). 75 (1) ,1-16.

18. Mensah, S., Aboh, A., Salifou, S., Mensah, G., Sanders, P., Abiola, F., \& Koudandé, O. (2014). Risques dus aux résidus d'antibiotiques détectés dans le lait de vache produit dans le Centre Bénin. Journal of Applied Biosciences, 80(1), 7102-7112.

19. Okombe, E., Luboya, L., Nzuzi, M., \& Pongombo, S. (2017). Detection des residus d'antibiotiques dans les denrees alimentaires d'origine animale commercialisees a lubumbashi en Republique Democratique du Congo. Agronomie Africaine, 29(3), 207-216.

20. Okombe, E. V., Luboya, W. L. R., Nzuzi, M. G., \& Pongombo, S. C. (2016). Détection des résidus d'antibiotiques dans les denrées alimentaires d'origine bovine et aviaire commercialisées à Lubumbashi (RD Congo). Journal of Applied Biosciences, 102(1), 9763-9770.

21. Traoré, O. Z., \& Tamini, L. D. (2019). Effet des Limites Maximales de Résidus de Pesticides imposées par les pays de l'OCDE sur les Exportations des pays Africains-Exemple des Mangues. la santé animales de la FAO., No. 9. Rome.

\section{Figures}

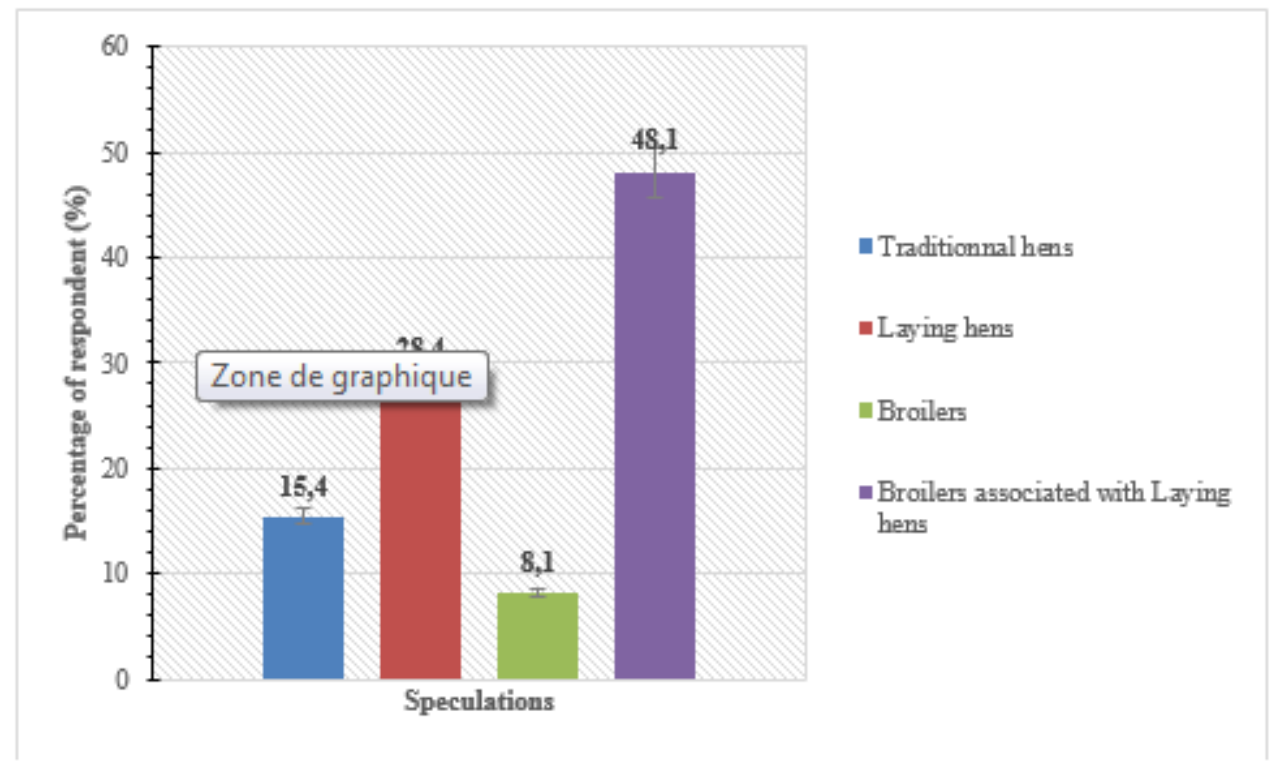

\section{Figure 1}

speculations sold into Lomé markets 